\title{
EKOPEDAGOGIK: ANALISIS POLA PENDIDIKAN DI SEKOLAH ALAM BANDUNG
}

\author{
Hana Yunansah ${ }^{1}$, Kuswanto $^{2}$, Fauzi Abdillah ${ }^{3}$ \\ 1,2 Universitas Pendidikan Indonesia, Kampus Cibiru \\ ${ }^{3}$ Universitas Negeri Jakarta
}

\begin{abstract}
Human understanding of the environment has led his life in a condition called "unsustainable for development". A situation where human life is unbalanced due to human activities that tend more to exploit the environment than preserve the natural resources that exist. In other words, human beings tend to be more use and forget to keep the environment itself, so that it causes environmental crisis. The perspective errors can reduce the human ecological values, which in fact they have a relationship of space and time with nature, therefore humans play a role as subjects in life that have the will to interact with nature. They can use nature according to their will, or they will manage nature according to their conscience for the sake of sustainability, harmony, harmony of life. This research aims to find facts about the pattern of ecopedagogic education in the School of Natural Bandung. This research uses a qualitative approach with a case study method. Data collection techniques in the form of interviews and observations, secondary data includes data collection techniques in the form of literature studies and documentation studies. Based on the results of research, education pattern that is applied in the School of Natural Bandung, humanist pattern, a pattern of religious and democratic pattern. The education pattern oriented to the development potential of learners through the integration of subjects and learning support activities.
\end{abstract}

Keyword: Ecopedagogic, Educational Patterns

\begin{abstract}
Abstrak: Pemahaman manusia terhadap lingkungan telah mengantarkan kehidupannya pada kondisi yang disebut "unsustainable for development". Suatu keadaan dimana kehidupan manusia tidak seimbang dikarenakan ulah manusia yang cenderung lebih banyak mengeksploitasi lingkungan daripada memelihara sumber-sumber alam yang ada. Dengan kata lain manusia cenderung lebih banyak memanfaatkan dan lupa menjaga lingkungan itu sendiri, sehingga hal ini menyebabkan terjadinya krisis lingkungan. Kesalahan sudut pandang tersebut mampu mereduksi nilai-nilai ekologis manusia, yang sejatinya mereka memiliki relasi ruang dan waktu dengan alamnya, oleh sebab itu manusia memegang peran sebagai subjek dalam kehidupan yang memiliki kehendak untuk berinteraksi dengan alam. Mereka dapat memanfaatkan alam sesuai kehendaknya, ataupun mereka akan mengelola alam sesuai hati nuraninya demi kelestarian, keharmonisan, keselarasan hidup. Penelitian ini bertujuan untuk menemukan fakta tentang pola pendidikan ekopedagogik pada Sekolah Alam Bandung. Penelitian ini menggunakan pendekatan kualitatif dengan metode studi kasus. Teknik pengumpulan data berupa wawancara dan observasi, data sekunder mencakup teknik pengumpulan data berupa studi literatur dan studi dokumentasi. Berdasarkan hasil penelitian, pola pendidikan yang diterapkan di Sekolah Alam Bandung yaitu pola humanis, pola religius, dan pola demokratis. pola pendidikan tersebut berorientasi kepada pengembangan potensi peserta didik melalui kegiatan pengintegrasian mata pelajaran, dan kegiatan penunjang pembelajaran.
\end{abstract}

Kata Kunci: Ekopedagogik, Pola Pendidikan

\footnotetext{
'Universitas Pendidikan Indonesia, Kampus Cibiru, Email: hanayunansah 国upi.edu

${ }^{2}$ Universitas Pendidikan Indonesia, Kampus Cibiru, Email: kuswanta.8回upi.edu

${ }^{3}$ Universitas Negeri Jakarta, Email: abdillah国uni.ac.id
} 


\section{PENDAHULUAN}

Pendidikan merupakan suatu hal yang sangat penting dalam kehidupan berbangsa dan bernegara. Negara bisa maju melalui pendidikan karena dengan pendidikan akan membangun sumber daya manusia yang memiliki kompetensi yang berkualitas. Pendidikan merupakan media strategis dalam memacu sumber daya manusia dalam membangun sebuah peradaban. Muslich (2011. Hlm, 67) mengungkapkan bahwa pendidikan merupakan suatu proses dimana suatu bangsa mempersiapkan generasi mudanya untuk menjalankan kehidupan dan untuk memenuhi tujuan hidup secara efektif dan efisien.

Konsep pendidikan yang ideal pada dewasa ini yaitu yang memandangan bahwa pendidikan dimaknai sebagai proses humanisasi. Pada konsep ini mengemukakan bahwa arti humanisasi ialah adanya pola interaksi yang positif antara pendidik dan peserta didik yang mengupayakan agar peseta didik dapat mengembangkan potensi yang dimilikinya. Dalam proses pengembangan potensi manusia, maka sudah seharusnya dirumuskan atau direncanakan suatu pendidikan yang mampu memberikan wadah dalam mengupayakan pengembangan potensi setiap individu yang beraneka ragam.

Melihat dari konsep pendidikan tersebut, apabila pendidikan dipahami sebagai serangkaian aktifitas yang bersifat mekanistik, maka pendidikan itu belum sampai kepada sesuatu hal yang membuat manusia merasa merdeka. artinya ada yang bermasalah dengan pola pendidikannya.

Pola pendidikan dapat dimaknai sebagai suatu gambaran aktivitas pendidikan yang tersitematisasi atau memiliki kerangka kerja yang jelas. Jika dipahami pola pendidikan secara makro maka dapat didefinisikan sebagai sistem pendidikan, sedangkan pola pendidikan secara mikro dapat dimaknai sebagai sintaks pembelajaran. Oleh karena itu pola pendidikan dikhususkan pada aktivitas mendidik yang memiliki jangka waktu yang panjang dan berkesinambungan.

Melanjutkan dari konsep di atas, bahwa dalam hal ini pendidikan memberikan peranan konstruktif dalam kehidupan manusia yang berperadaban. Oleh sebab itu, sejatinya pendidikan mampu membangun manusia sebagai subjek dari kehidupan untuk memahami peran dan fungsinya dalam kehidupan ini. Sehingga pendidikan merupakan suatu proses yang tidak ada akhirnya (never ending process). Lebih lanjut Tilaar (2012) menyatakan bahwa pendidikan merupakan suatu upaya manusia belajar " a process be coming". Hal tersebut dimaknai bahwa dengan belajar manusia mampu mengambil pilihan yang dianggap baik untuk dirinya dengan mengaktualisasikan dirinya dengan lingkungannya, atau dengan kata lain proses tersebut merupakan suatu pencarian makna diri seseorang melalui proses belajarnya.

Senada dengan pernyataan di atas bahwa kegiatan pendidikan tidak terjadi pada kekosongan tanpa makna, tetapi adanya interaksi yang dihayati oleh pendidik dan peserta didik sesuai dengan situasi psikologis anak. Interaksi yang bersifat humanis mampu mengatarkan peserta didik pada hakikat manusianya. Dalam sudut pandang lain, bahwa manusia merupakan sebagai makhluk multidimensional (Herlambang, 2018), yang salah satunya ialah memiliki hubungan dengan alam atau lingkungan, sehingga pengembangan manusia dalam proses pendidikan tidaklah terpisah dari hakikatnya tersebut, dan akan senantiasa terkait erat dengan ruang dan waktu saat relasi antara manusia dengan lingkungan alam mendapat tempatnya secara nyata (Yunansah, \& Herlambang, 2017). Hal ini berimplikasi secara praktis pada kewajiban manusia untuk selalu menjaga keselarasan, keharmonisan, dan kesinambungan dengan 
alam (Muhaimin, 2015). Hal ini dikarenakan manusia, dianggap sebagai bagian dari planet bumi (Freire, 2010; Misiaszek, 2012). Berkaitan hal diatas, hal tersebut berbanding terbalik dengan realitas yang ada saat ini. Meskipun pada dasarnya alam sendiri sudah diakui memiliki nilai dan berharga, tetapi pada kenyataannya, alam dianggap sebagai objek kehidupan yang terus di eksploitasi oleh manusia melalui praktik pencemaran, perusakan dan berbagai tindakan buruk lainnya. Kondisi ini merupakan cerminan dari rendahnya kesadaran ekologis masyarakat.

Berdasarkan hal tersebut, pendidikan ekologis sangat dibutuhkan sebagai upaya dalam melakukan refleksi kritis atas kondisi tersebut. apabila pendidikan dilaksanakan dengan menerapkan pola-pola yang konservatif dengan menekankan pada proses transfer of knowladge maka hanya akan membuat peserta didik hanya sebatas memiliki pengetahuan tentang lingkungan, dan kurang memiliki kesadaran dan kepedulian terhadap lingkungan (Muhaimin, 2015).

Berikut ini merupakan penelitian yang sudah dilakukan oleh Muhaimin (2015) yang berjudul Implementasi Model Pembelajaran Berbasis Masalah Lokal dalam Mengembangkan Kompetensi Ekologis pada Pembelajaran IPS. Penelitian tersebut sudah menunjukkan hasil yang cukup baik, hal ini terlihat dari hasil pembelajaran IPS mengalami peningkatan secara signifikan dan model Ecopedagogy-BMLHL lebih efektif meningkatkan kompetensi ekologis peserta didik. Namun, dari penelitian tersebut lebih menekankan pada segi konten (materi pelajaran) saja, belum sampai menyentuh kepada hal yang bersifat fundamental terkait ekopedagogik itu sendiri. Dari hasil tersebut, terdapat permasalahan bahwa ekopedagogik bukan dipahami sebagai teknik/metode pembelajaran yang mampu meningkatkan kesadaran ekologis. Namun lebih dari hal itu, yakni berorientasi kepada penginternalisasian nilai-nilai atau etika lingkungan, dengan melihat pola pendidikan yang dilaksanakan di persekolahan. Sehingga ekopedagogik tidak dipahami secara parsial yaitu sebagai pengetahuan terkait lingkungan, tapi bagaimana siswa menginterpretasikan dirinya terhadap lingkungan itu sendiri. Oleh sebab itu dirasa perlu dilakukan penelitian lanjutan, dengan melakukan pemahaman secara komprehensif terkait konsep ekopedagogik tersebut.

Ekopedagogik dapat diartikan sebagai gerakan akademik untuk menyadarkan para peserta didik menjadi seorang individu yang memiliki pemahaman, kesadaran dan keterampilan hidup selaras dengan kepentingan pelestarian alam (Kahn, 2010). Dalam pengertian berbeda (Gadotti, 2010) berpendapat bahwa ekopedagogik merupakan sebuah pendekatan dalam pembelajaran yang menjadikan para peserta didik sebagai pembelajar yang mandiri, otonom, mampu mengembangkan potensi belajar berdasarkan pengalaman yang dibawa dari luar kelas serta menyadari bahwa setiap tindakannya berdampak pada diri dan lingkungannya.

Berdasarkan dari permasalahan tersebut, artikel ini dibuat dengan bertujuan untuk menganalisis pola pendidikan ekopedagogik yang dilaksanakan di sekolah alam bandung. Adapun orientasi ekopedagogik sendiri yaitu menekankan kepada peningkatan kesadaran ekologis manusia untuk menjaga, merawat, dan melestarikan alam. Serta diharapkan mampu menginternalisasikan nilai-nilai ekopedagogik dalam diri manusia.

\section{METODOLOGI PENELITIAN}

Metode yang digunakan dalam penelitian ini adalah studi kasus dengan pendekatan kualitatif. Penelitian ini dilakukan pada Sekolah Alam Bandung. Pemilihan sekolah ini dianggap peneliti dapat memberikan informasi yang lengkap tentang permasalahan dalam penelitian ini. 
Selain itu juga sekolah ini merupakan sekolah yang memiliki komitmen dalam melaksanakan pendidikan yang tidak hanya berorientasi pada pengembangan kurikulum pemerinta/pusat, melainkan juga berorientasi pada penerapan pendidikan ekopedagogik, yaitu konsep belajar dengan membawa siswa berinteraksi langsung dengan alam. Hal ini bermaksud agar siswa memiliki kesadaran tentang nilai-nilai lingkungan.

Penelitian ini bertujuan untuk menemukan fakta tentang pola pendidikan ekopedagogik di Sekolah Alam Bandung. Informan peneliti terdiri dari Kepala Sekolah, Guru (wali kelas) dan peserta didik. Hasil pengumpulan data yang diperoleh melalui teknik wawancara, observasi, dan dokumentasi kemudian dianalisis menggunakan model Milles dan Huberman. Teknis analisis tersebut terdiri dari reduksi data, penyajian data, dan verifikasi data (Milles dan Huberman, 2012). Data yang berhasil diperoleh kemudian divalidasi menggunakan teknik pengumpulan data.

\section{HASIL PENELITIAN DAN PEMBAHASAN}

Hasil penelitian secara eksplisit tentang Sekolah Alam Bandung, yang meliputi profil sekolah, program pendidikan, dan implementasi pendidikan ekopedagogik di Sekolah Alam Bandung.

1. Temuan Profil Sekolah Alam Bandung.

Berdasarkan hasil observasi yang telah dilaksanakan oleh peneliti, diperoleh temuan yang bersumber dari data dan dokumen resmi yang dimiliki oleh pihak sekolah seperti gambaran umum lokasi penelitian (profil sekolah) dan dokumen kurikulum sekolah. Hal ini merupakan data yang dibutuhkan oleh peneliti agar relevan dengan tujuan penelitian yang akan dilaksanakan, berikut ini merupakan dokumen profil sekolah.

Sekolah Alam Bandung beralamat di jalan Cikalapa II Nomor. 04, RT 09 RW 03 Kampung Tanggulang Dago Pojok. Kelurahan Dago, Kecamatan Coblong,
Kota Bandung. Dengan memiliki luas tanah $5.334 \mathrm{~m}^{2}$ yang berstatus tanahnya sewa, sertifikat tanah 4678, dan SK pendirian 421.2/3737/DISDIK/2016

Pada tahap pelaksanaan pendidikan di Sekolah Alam Bandung memiliki Visi yaitu menjadi institusi atau lembaga pendidikan yang mengarah dan berbasis kepada Al-Quran dan Sunnah "back to nature" dan "sustainable development".

Selain itu Misi Sekolah Alam Bandung yaitu mengembangkan tiga aspek pendidikan yang meliputi pengembangan akhlakul karimah (sikap hidup), falsafah ilmu pengetahuan (logika berfikir), kepemimpinan (leadership), Sekolah Alam Bandung merancang kurikulum berdasarkan landasan filosofis Al-Quran yaitu dapat dijelaskan dalam ayat-ayat berikut ini.

1) Sesungguhnya, yang paling mulia diantara kamu di sisi Allah adalah orang yang paling bertakwa. Sesungguhnya Allah Maha Mengetahui, Maha Teliti” (QS. AlHujurat: 13)

2) "Niscaya Allah akan mengangkat (derajat) orang-orang yang beriman diantara kamu dan orang-orang yang diberi ilmu beberapa derajat. Dan Allah Maha Teliti apa yang kamu kerjakan”.

Berdasarkan dari ketiga ayat tersbut dapat dimaknai bahwa manusia diciptakan adalah sebagai khalifah dimuka bumi, artinya keberadaan manusia sebagai pemimpin di bumi berupaya untuk menjaga keselarasan, keharmonisan, dan keseimbangan alam. Namun dari realita yang ada alam dianggap sebagai objek kehidupan yang terus dieksploitasi oleh manusia melalui praktik pencemaran dan perusakan. Oleh karena itu pengembangan aspek pendidikan yang dirancang Sekolah Alam Bandung mampu berkontribusi dalam mewujudkan insan-insan pendidikan yang memiliki kesadaran tentang nilai-nilai alam atau lingkungan, bukan diorientasikan pada upaya untuk 
melahirkan insan-insan pendidikan yang berjiwa pragmatis-materialis.

Berpijak dari landasan filosofis tersebut, dalam implementasinya sekolah menerapkan konsep pendidikan berbasis pada alam. Alam yang dimaksud bukan dari hal yang bersifat kongkrit, melainkan konsep alam secara holistik atau dalam hal ini dimaknai sebagai alam semesta. Sehingga Sekolah Alam Bandung menerapkan strategi pendidikan dengan menyisipkan unsur-unsur religi dan membangun kesadaran lingkungan dalam pelaksanaan pendidikannya.

Hal tersebut sesuai dengan hasil wawancara dengan (ibu Wiwid Hasanah, S.Pd) mengatakan bahwa rancagan program yang diterapkan di Sekolah Alam Bandung yaitu berlandaskan dari tiga aspek yang sudah dijelaskan di atas. Pertama, akhlaqul karimah yang tadi landasannya bersumber pada $\mathrm{Al}$ Quran, lalu ada leadership yang mana tentang kepemimpinan, dengan diadakannya outbond. Sehingga pembelajaran lebih menekankan kepada akhlak dan adab dulu sebelum ilmu. Mulai dari hal terkecil yang berkaitan dengan alam, membuang sampah pada tempatnya, mengucapkan salam, pembiasaan itu terdapat dalam pembentukan akhlaqul karimah. Kemudian leadership yang mana manusia adalah khalifah yang ada di bumi, disitu anakanak diajarkan untuk berani, untuk bertanggung jawab, untuk belajar kepemimpinan salah satunya dengan kegiatan outbond dimasing-masing kelas, yang tingkatannya sudah berbeda. Selanjutnya falsafah ilmu pengetahuan, disini ilmunya yang meliputi matematika, sosial, sains dan lain-lain.

Selanjutnya tujuan pendidikan Sekolah Alam Bandung adalah sebagai bagian tujuan pendidikan nasional, yakni berkembanganya potensi peserta didik agar menjadi manusia yang beriman dan bertakwa kepada Tuhan Yang Maha Esa, berakhlak mulia, sehat, berilmu, cakap, kreatif, mandiri, dan menjadi warga negara yang bertanggung jawab, serta dapat mengikuti pendidikan lebih lanjut.

2. Temuan Program Pendidikan Sekolah Alam Bandung

Berdasarkan hasil studi dokumentasi dan wawancara dengan guru bagian kurikulum di Sekolah Alam Bandung, bahwa dalam kegiatan belajar mengajar, sekolah menggunakan kurikulum Departemen Pendidikan Nasional sebagai dasar dalam pelaksanaan peendidikan. disamping itu sekolah juga mengembangkan kurikulum sendiri sesuai dengan konteks dan konsep pendidikan yang menjadi ciri khas sekolah tersebut. Adapun kurikulum Sekolah Alam Bandung akan dipaparkan sebagai berikut.

a. Kurikulum Sekolah Alam Bandung Sekolah Alam Bandung menekankan proses pembelajaran yang disampaikan secara aktif dan fun, karena secara lahiriah anak lebih suka berada dalam ruangan formal, tertutup dengan lingkungan yang terbatas.

Dalam berkreasi di lingkungan sekolah yang terbuka dan bebas, maka anak dapat menikmati waktu sekolah mereka, sehingga pengembangan nilai kreatifitas dan kemampuan dirinya menjadi lebih efektif.

Sistem pengembangan pendidikan yang utama adalah dengan cara memberikan kepercayaan, sikap positif pada diri anak terhadap lingkungannya, karena perkembangan intelektualitas, emosional dan spiritual quotient sangat dipengaruhi oleh lingkungan alam sekitar, sehingga anak dapat mengembangkan nilai kepemimpinannya, memiliki emosi yang stabil dan dapat bekeja dalam suatu kelompok.

Dengan metode berpetualang di alam bebas, anak dapat menerapkan proses belajar mengajar secara holistik dan dapat menciptakan suatu perkembangan bakat secara fisik dengan menggabungkan nilai emosi pada dirinya dan kerja kelompok bersama teman-temannya. 
Kurikulum Sekolah Alam Bandung meliputi tiga kurikulum khas sekolah alam yang mengacu pada sistem kurikulum pendidikan nasional.

b. Kurikulum Khas

- Akhlakul karimah (sikap hidup), metode utama dalam pembelajaran yaitu keteladanan, membentuk perilaku manusia yang sesuai dengan Al-Quran dan As-Sunnah. Melalui pengenalan terhadap ciptaan Allah, dan penghargaan lingkungan selain dirinya.

- Falsafah ilmu pengetahuan (logika berpikir), metode utamanya action learning dan diskusi. Yaitu membiasakan berpikir secara logis dan mendorong rasa ingin tahu, dengan melihat gejala alam yang tengah berlansung.

- Latihan kepemimpinan (leadership), metode utamanya outbond, wirausaha, tani-ternak terpadu, pengalaman bekerja sama dalam kelompok, melatih rasa percaya diri, berdisiplin dan membentuk kemandirian.

3. Temuan Implementasi Pendidikan Ekopedagogik pada Sekolah Alam Bandung

Proses internalisasi ekopedagogik di Sekolah Dasar Sekolah Alam Bandung, dilakukan melalui beberapa tahap kegiatan yang meliputi, 1) Kegiatan pembelajaran pembelajaran di dalam kelas, melalui kegiatan pengintegrasian mata pelajaran, 2) Program penunjang pembelajaran melalui beberapa kegiatan seperti outbound, kewirausahaan, dan tani-ternak, dan 3) Melalui kegiatan-kegiatan pembiasaan yang diterapkan di sekolah.

Berdasarkan hasil penelitian, bahwa internalisasi nilai ekopedagogik dalam pembelajaran dilakukan melalui pembiasaan dengan melakukan kegiatan buka kelas, kegitan ini bertujuan untuk memotivasi siswa agar mereka merasa senang dan siap untuk belajar dengan memberikan kesempatan kepada siswa untuk melakukan aktivitas yang dapat memberikan pengalaman bagi dirinya dengan berinteraksi langsung di alam. Serta setelah itu adanya kegiatan mengaji sebelum kegiatan pembelajaran.

\section{Pembahasan}

Pembahasan ditinjau secara teoretis dengan berlandaskan dari teori ekopedagogik yang berorientasi kesadaran lingkungan yang perlu dihayati oleh peserta didik.

Visi Sekolah Alam Bandung yaitu menjadi institusi atau lembaga pendidikan yang mengarah dan berbasis kepada AlQuran dan Sunnah, "back to nature" dan "sustainable development". Sekolah Alam Bandung berorientasi pada pencapaian kompetensi yang secara eksplisit tertuang dalam indikator pencapaian pada setiap mata pelajaran, melainkan bertujuan pada upaya membentuk jati diri peserta didik sebagai manusia yang berilmu, berakhlak, arif dan bijak dalam menjaga lingkungan. Hal tersebut sejalan dengan pendapat Supriatna (2012, hlm. 176) dalam perspektif ekopedagogik menyatakan:

Para siswa harus diberdayaka untuk memiliki pandangan kritis tentang pembangunan berkelanjutan (sustainable development) dan keterbatasan sumber daya alam, serta kemampuan beradaptasi dengan lingkungan yang semakin berubah agar power (kuasa) melekat pada diri mereka sehingga tidak menjadi korban dari hegemoni kelompok lain. Hal ini juga relevan dengan dengan green curriculum yang dapat berisi program pendidikan yang didalamnya menyiapkan peserta didik memiliki pemahaman dan keterampilan untuk menunjang pembangunan yang berkelanjutan (sustainable development).

Melihat dari beberapa pernyataan yang sudah disampaikan di atas, dapat dimaknai bahwa ekopedagogik merupkan suatu pendekatan pendidikan yang berupaya untuk mengubah perilaku dan sikap yang dilakukan oleh berbagai pihak atau elemen masyarakat yang bertujuan untuk meningkatkan pengetahuan, keterampilan, kesadaran masyarakat tentang nilai/etika lingkungan, dan isu 
permasalahan lingkungan yang pada akhirnya dapat menggerakan masyarakat untuk berperan aktif dalam upaya pelestarian dan keselamatan lingkungan untuk kepentingan generasi sekarang dan yang akan datang. Hal tersebut berkorelasi dengan apa yang menjadi tujuan dari pendidikan lingkungan.

Dalam membangun efektivitas internalisasi nilai-nilai ekopedagogik, proses pendidikan yang berlangsung, haruslah pendidikan yang diorientasikan pada nilai-nilai ekologis. Hal ini sejalan dengan pendapat Muhaimin (2015) yang menyampaikan bahwa pendidikan yang membangun kesadaran dan kecerdasan ekologis dengan berorientasi pada transfer of knowledge akan membuat peserta didik hanya sebatas memiliki pengetahuan tentang lingkungan, dan kurang memiliki kesadaran dan kepedulian terhadap lingkungan.

Terkait dengan pendapat di atas, Surata (2010) mengungkapkan bahwa sebagai basis pendidikan pembangunan berkelanjutan, ekopedagogik menawarkan empat sistem pengajaran: (1) pengajaran tentang lingkungan sosial dan alam, yakni menyiapkan teks-teks terkait lingkungan hidup bagi anak-anak sehingga memampukan mereka menyingkapkan isuisu lingkungan terkini, akar dari isu, serta strategi untuk menanggapi isu, baik secara individu maupun kolektif; (2) pengajaran dalam lingkungan sosial dan alam, yakni menuntun para pelajar kepada kesadaran akan relasi mereka dengan lingkungan, baik sosial maupun alam; (3) pengajaran melalui lingkungan sosial dan alam, yakni mengadaptasi tugas-tugas kelas, latihan menulis, kerja kelompok, pengalaman, perjanjian dengan masyarakat untuk menjelmakan pengetahuan ke dalam aksi sosial, keadilan lingkungan, kesejahteraan dan keberlanjutan; (4) pengajaran tentang kesalingterkaitan antar makhluk yang berkelanjutan.

Selain itu pada hakikatnya rancangan program pendidikan Sekolah Alam Bandung menerapkan kurikulum yang digunakan di sekolah pada umumnya yaitu menggunakan kurikulum 2013, artinya dari segi kurikulum secara prosedural Sekolah Alam Bandung mengikuti sistem pendidikan yang sudah diterapkan oleh pemerintah, namun secara operasionalnya terdapat sebuah improvisasi atau pengembangan, dimana dalam pelaksanaanya Sekolah Alam Bandung memiliki kurikulum khas, yang meliputi aspek pengembangan akhlakul karimah (sikap hidup), falsafah ilmu pengetahuan (logika berfikir), kepemimpinan (leadership). hal ini dapat dimaknai bahwa tujuan kurikulum tidak hanya didasarkan pada hal yang bersifat tekstual, melainkan juga pada hal yang bersifat kontekstual atau dalam pengembangannya senantiasa dikaitkan dengan lingkungan dan budaya setempat.

Terkait dengan pernyataan di atas, Aliyeva (2016, hlm. 14) menyatakan whole curricullum ada kaitanya dengan rumusan kurikulum yang menyatakan bahwa "Curriculum all the learning experience planned and guided by school". Konsep kurikulum tersebut berkenaan dengan lingkungan belajar total dengan pengembangan diri peserta didik secara menyeluruh, atau dapat dipahami bahwa whole curriculum merupakan kurikulum secara keseluruhan dalam ruang lingkup persekolahan dan jangka panjang, serta bersifat lebih formal. Selain itu (Fitroh, 2011) mengemukakan bahwa terdapat lima prinsip dalam mengembangkan kurikulum, prinsipprinsip tersebut adalah 1) Prinsip relevansi, secara internal bahwa kurikulum memiliki relevasi diantara komponen kurikulum, 2) Prinsip fleksibilitas, 3) Prinsip kontinuitas, 4) Prinsip efisiensi, dan 5) prinsip efektivitas.

Proses internalisasi nilai-nilai ekopedagogik yang dilakukan melalui kegiatan pembelajaran di kelas yaitu melalui pengintegrasian pada mata pelajaran yang telah ada melalui kontekstualisasi materi pelajaran dan melalui pembiasaan yang dilakukan oleh 
pendidik dan peserta didik sebelum melakukan pembelajaran, selain itu proses internalisasi nilai ekopedagogik juga dilakukan dalam kegiatan penunjang pembelajaran yang meliputi kegiatan outbound, kewirausahaan, dan tani-ternak. Hal ini dimaksudkan agar siswa tidak memahami unsur-unsur ekopedagogik secara parsial, melainkan memahaminya secara utuh dengan membangun kesadaran dan tanggung jawab terhadap lingkungan hidup termasuk melakukan upaya-upaya yang senantiasa selaras dengan pelestarian dan keseimbangan lingkungan. Senada dengan pernyatan tersebut, Hamzah (2013) mengungkapkan bahwa kepedulian terhadap lingkungan hidup merupakan wujud mental individu yang direfleksikan dalam perilakunya. Sikap mental terhadap lingkungan bukan talenta atau insting bawaan, tetapi merupakan hasil dari suatu proses pendidikan.

Selanjutnya proses internalisasi nilai ekopedagogik dilakukan melalui manajemen sekolah yang diterapkan dalam bentuk peraturan atau tata tertib sekolah. manajemen sekolah ini secara langsung memberikan panduan untuk menjalani kehidupan di lingkungan sekolah. manajemen tersebut diterapkan melalui beberapa kegiatan diantaranya, kegiatan buka kelas, sholat duha berjamaah, membaca ayat suci Al-Quran. Penerapan pembiasaan tersebut dilakukan oleh seluruh elemen sekolah, baik itu oleh siswa, guru, maupun kepala sekolah. Hal ini dimaksudkan agar muncul sebuah kesadaran dalam diri manusia terkait hubungan dirinya dengan alam.

Pendapat di atas dimaknai bahwa proses internalisasi nilai-nilai ekopedagogik. Secara implementatif, ekopedagogik dilakukan dalam berbagai kegiatan pembelajaran yang terintegrasi dengan setiap mata pelajaran, kegiatan penunjang pembelajaran, dan manajemen sekolah melalui tata tertib sekolah, serta kegiatan-kegiatan pembiasaan lainnya. berdasarkan penelitian tersebut dapat dimaknai bahwa pada umumnya respon dan aktivitas siswa dalam pembelajaran cukup positif. Hal ini dikarenakan selama pembelajaran berlangsung siswa menunjukkan respon yang positif dengan motivasi dan atusias yang cukup tinggi. Serta dengan pembelajaran yang menekankan kepada siswa untuk bereksplorasi dalam proses belajarnya, yaitu menempatkan siswa sebagai subjek pebelajar yang aktif membangun pengetahuannya sendiri berdasarkan pengalamannya. Sehingga dengan iklim pembelajaran tersebut maka sekolah dapat mewujudkan pola pendidikan yang humanis, demokratis, dan religius. Adapun pola pendidikan yang dimaksud akan disajikan dalam bentuk tabel berikut ini.

\begin{tabular}{|c|c|c|c|}
\hline \multicolumn{4}{|c|}{ Tabel 4.10 Tentang pola pendidkan Ekopedagogik terhadap komponen pendidikan } \\
\hline $\begin{array}{r}\text { Komponen } \\
\text { pondidikan } \\
\text { pola }\end{array}$ & Pola humanis & Pola demokratis & Pola religius \\
\hline Tujuan pendidikan & 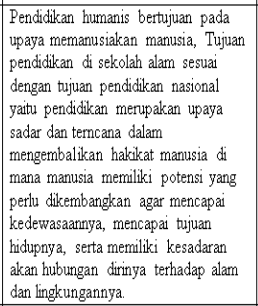 & 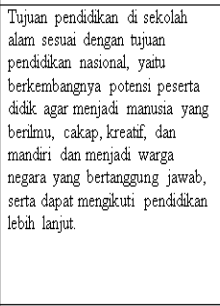 & 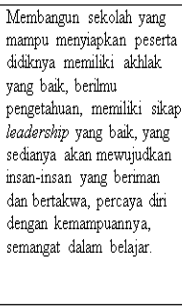 \\
\hline Isi pendidikan. & 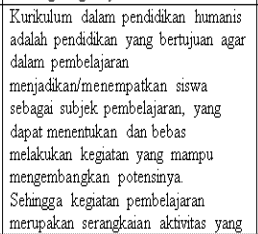 & 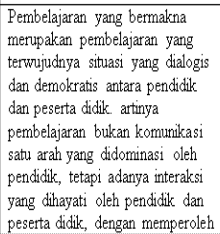 & 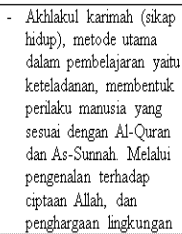 \\
\hline
\end{tabular}

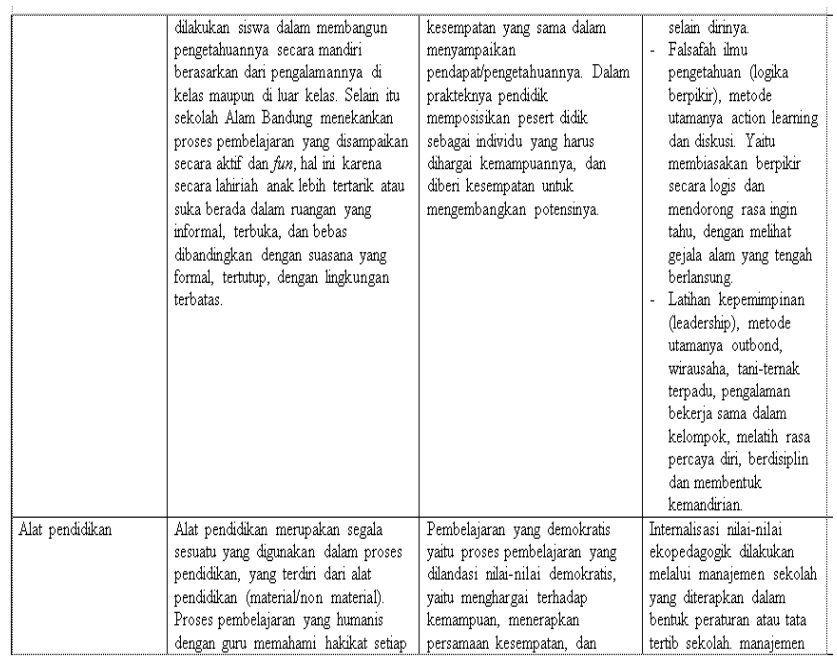



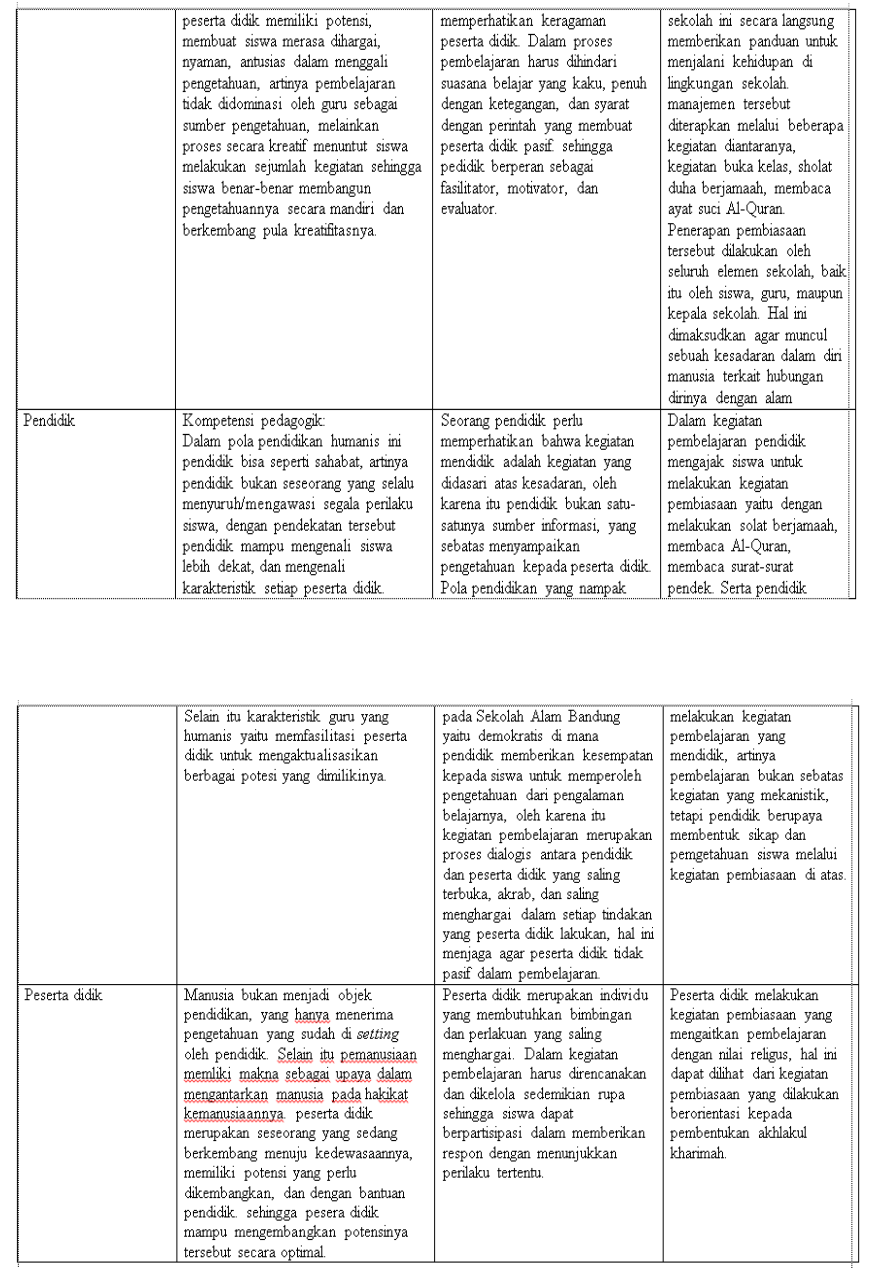

KESIMPULAN

Berdasarkan hasil penelitian yang sudah dipaparkan di atas, maka dapat dimaknai bahwa dalam pelaksanaan pendidikan di sekolah alama bandung mengimplementasi proses pembelajaran yang berbasis pada ekopedagogik.

Ekopedagogik merupakan suatu pendekatan pendidikan yang menitikberatkan pada upaya dalam menginternalisasi nilai-nilai ekologis dalam proses pembelajaran. Selain itu pola Pendidikan yang diterapkan di sekolah alam bandung yaitu berlandaskan pada pengembangan nilai-nilai kemanusiaan (humanisasi) dan religiusitas dari setiap peserta didiknya. Pola Pendidikan tersebut dapat ditinjau dari enam komponen pendidikan, sehingga dapat disimpulkan bahwa sekolah alam bandung menerapkan pola pendidikan yang humanis, demokratis, dan relligius. Hal ini terlihat dari proses internalisasi nilai-nilai ekopedagogik pada implementasinya dilakukan dalam kegiatan pengintegrasian mata pelajaran, kegiatan penunjang pembelajaran, yang meliputi kegiatan outbound, kewirausahaan, dan tani ternak.

\section{DAFTAR PUSTAKA}

Aliyeva, E. (2016). An Overview of the National Curriculum Development Process for Azerbaijan. the Online Journal of New Horizons in Education. Vol. 6, Issue 1, Januari 2016. Dalam www.tojned.net [diakses tanggal 5 Februari 2018].

Fitroh (2011). "Pengembangan Kurikulum Berbasis Kompetensi dan Strategi Pencapaian". Jurnal sistem informasi universitas indonesia, 4, (2), 1-7.

Freire, P. (2010). Pedagogy of the oppressed. New York: The Continuum International Publishing Group Inc. (MB. Ramos, Trans). New York: Continuum 2007

Gadotti, M. (2010). Reorienting Education Practice Toward Sustainability. Journal of education for sustainability, 2010, 4.(2) 203-201.

Hamzah, S. (2013). Pendidikan Lingkungan Hidup, Sekelumit Wawasan Pengantar. Bandung: Refika Aditama

Herlambang (2018). Pedagogik Telaah Kritis Ilmu Pendidikan dalam Multiperspektif. Jakarta: Bumi Aksara.

Kahn, R. (2010). Critical pedagogy, ecoliteracy \& planetary crisis. The ecopedagogy movement. (Vol.359) NY: Peter Lang.

Miles, M. \& Huberman, A. M. (2012). Analisis Data Kualitatif Buku, Jakarta: Universitas Indonesia Press.

Misiaszek, G. W. (2012). Transformative environmental education within social justice models: Lessons from comparing adult ecopedagogy within North and South America. In 
D. N. Aspin, J. Chapman, K. Evans \& R. Bagnall (Ed.).Second International Handbook of Lifelong Learning (Vol. 26, pp. 423-440). London: Springer.

Muhaimin (2015). Implementasi Model Pembelajaran Berbasis Masalah Lokal dalam mengembangkan kompetensi ekologis pada Pembelajaran IPS. Sosio didaktika. Social science educational journal. 2(1), 12-21

Muslich, M. (2011). Pendidikan Karakter Menjawab Tantangan Krisis Multidimensional. Jakarta: Bumi Aksara.

Supriatna, N. (2012). Ecopedagogy dan Green Curriculum dalam pembelajaran sejarah dalam pendidikan sejarah untuk manusia dan kemanusiaan. Editor: Hasiswany Kamarga dan Yani Kusmarini. Jakarta: Bee Media

Surata, K. (2010). Pembelajaran Lintas Budaya: Penggunaan Subak sebagai Model "Ecopedagogy". Jurnal Kajian Bali. 03, (02).

Tilaar, H.A.R. (2012). Perubahan Sosial dan Pendidikan: Pengantar Pedagogik Transformatif untuk Indonesia. Jakarta: Rineka Cipta

Yunansah, \& Herlambang (2017). Pendidikan Berbasis Ekopedagogik dalam Mengembangkan Karakter Siswa Sekolah Dasar. Jurnal Eduhumaniora. 1(9), 27-34. 